\title{
SHEAR BEHAVIOR OF SUSTAINABLE REINFORCED HIGH- STRENGTH CONCRETE BEAMS WITHOUT STIRRUPS
}

\section{* Ahmed Jawad Hassan'}

Nagham Tariq Al-Shafi' $i^{2}$

1) M.Sc. Student., Civil Engineering Department, Mustansiriya University, Baghdad, Iraq

2) Assist Prof. Dr., Civil Engineering Department, Mustansiriya University, Baghdad, Iraq

\begin{abstract}
This research raises the importance of using the recycled aggregates in constructions as an alternative solution to the conventional natural aggregates. Six specimens were cast and tested, using two types of natural and recycled aggregates. Two types of additive ratios of recycled aggregates including $50 \%$ and $100 \%$, were considered. During the cast, all beams had $1300 \mathrm{~mm}$ length and rectangular cross-section with breadth and height of 100 and $150 \mathrm{~mm}$, respectively. Steel fibers were added by $2 \%$ to 5 beams, while the last one without fibers. The test results provided considerable enhancement in shear capacity along with the considerable delay in the cracking load when steel fibers were added. The increasing in ultimate load regarding the beams which contain steel fibers by $2 \%$ is about $36 \%$ compared to the beams with a content of $0 \%$ for the same type of aggregate. It was noticed that the shear resistance of specimens containing $50 \%$ and $100 \%$ of untreated RCA decreased by $10.5 \%$ and $27.5 \%$, respectively compared to tests containing natural aggregates. In contrast, significant improvement in the shear resistance was recorded when using treated aggregates, whereas treated aggregate gave close results to normal aggregate. The discrepancy in the ultimate load for mixtures having $50 \%$ and $100 \%$ of treated RCA was only $1.9 \%$ and $9 \%$, respectively to the values gained from NSC.
\end{abstract}

Keywords: Normal Coarse Aggregate, Recycle Coarse Aggregate, Shear High strength Concrete, Steel fibers, Treatment of Recycle Coarse Aggregate

\section{Introduction}

Concrete can be considered as a major used material in the construction. The use of concrete has always been on a high level and will remain so in the future to meet its demand as an effective constructional material. The form of concrete mainly involves non-renewable elements such as natural aggregates. As the life span of an enormous number of concrete structures from the $20^{\text {th }}$ century comes to an end, the scale of demolishing is expected to be relentless. This process will cause the areas of landfills to increase where the air and groundwater pollutions will be a challenge. Needless to say, that the economic perspective will be adversely affected by high expenses on the removal of concrete from the demolition sites to the landfill zones, and complex process to bury the concrete wastes.

It is reported that the amount of demolition waste across the European Union is about 1 ton per capita with 450 million tons of concrete 
production per annum (Matias et al. 2014) [19]. However, the amount of demolition waste is much larger in some parts of the globe such as but not limited to the Middle East where destructive conflicts take place. One of the active missions to deal with the demolition wastes and protect the environment is to use the concrete wastes as recycled concrete aggregate in construction (see Figure (1)). Doing this process will enable the lower production and consumption of non-renewable natural resources such as coarse aggregates, minimize the air and groundwater pollutions, and reduce the landfill zones (Katkhuda and Shatarat, 2016) [17].

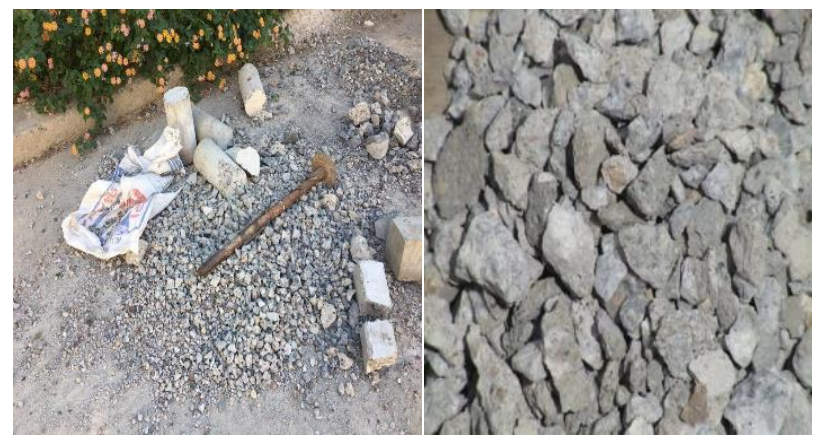

Figure 1. Using recycled coarse aggregates

To date, the primary application related to the recycled concrete aggregates (RCA) is limited to the secondary level activities such as road base and landfilling materials (Rao et al. 2007) [21]. Research is still being undertaken to examine the durability and mechanical properties of RCA. It is found that the microstructure of RCA is more complicated than the one in conventional concrete. This is because the RCA involves two types that are related to the interfacial transition zone (ITZ), one of them is between new mortar and RCA, while the other between old adhered mortar and RCA (Xiao et al. 2012) [27]. During the RCA production, the old adhered mortar would come with many micro-cracks which results in high porosity and weaker strength than natural aggregate. As a result, the low quality of
RCA will cause a significant drop in mechanical properties (modulus of elasticity, splitting tensile and compressive strengths) when compared to conventional concrete (Etxeberria et al. 2007)

The impact of replacement percentage related to recycled aggregate on structural behavior of the RC beams was investigated by Aly et al. (2015) [25]. Sixteen beams were tested until shear failure, and the parameters consisted of different ratios of $\operatorname{RCA}(0,25,50$ and $75 \%)$, various spandepth ratios (1, 1.5 and 2.0), and different locations of opening and reinforcement amounts. Results revealed that the optimal ratio of RCA was $50 \%$, which beyond caused a reduction in the shear capacity. It was concluded that employing the RCA as partial replacement is feasible to construct structural.

concrete parts. Furthermore, the high span-depth ratio was seen to lower the shear strength and vice versa. As for evaluating of Egyptian and ACI 318 code, the research showed that both codes provided conservative predictions to the values obtained from the experiment.

The shear strength related to $24 \mathrm{RC}$ beams containing fly ash and RCA was investigated by Sadati et al. (2016) [26]. The beam specimens were reinforced with three various longitudinal reinforcement ratios $(1.27,2.03$ and $2.71 \%$ ) with no stirrups in the shear zone. Four series of concrete casting were considered. The first series had only virgin concrete without fly ash or RCA. The second part contained a 50\% replacement of fly ash. The third cast had a $50 \%$ replacement of RCA. While the fourth series contained $50 \%$ fly ash and 50\% RCA. With the help of a statistical data analysis, the findings showed that the shear capacities of beams obtained from virgin concrete, $50 \%$ fly ash, and 50\% RCA were fairly close. However, the shear capacities of beams 
with both fly ash and RCA were $10 \%, 18 \%$ and $16 \%$ less than those obtained from virgin concrete, $50 \%$ fly ash, and 50\% RCA, respectively. The adequacy of using RCA as a replacement to the natural aggregate was assessed by Tabash and Yehia (2018) [28]. The study involved testing $3 \mathrm{RC}$ beams made with natural aggregate, 50\% RCA replacement and $100 \%$ RCA replacement. The beams were $1.5 \mathrm{~m}$ long and subjected to single-point load. The span-depth ratio was selected to be 1.5. Test results showed minor decrease in the shear capacity related to beams that are made with 50\% RCA compared to NSC beam, further decrease was noticed in the shear capacity in case of $100 \%$ RCA beam. However, the discrepancy in results were minimal.

Ashour et al. (1992) [3] performed 18 rectangular beams to study the shear behavior of high strength fiber reinforced concrete beams. The tested beams were made of high strength concrete ranging from $92-101 \mathrm{MPa}$ as well as longitudinal tensile reinforcement ratio $(\rho)$ varying from $0.4-4.6 \%$. Hooked steel fibers with a length of $60 \mathrm{~mm}$ and steel fiber volume fraction from $0.5-1.5 \%$ were considered. The authors noticed that the increase in the shear strength was due to the presence of steel fibers. The increase was up to $97 \%$ among beams having ald of 1.0 , while the increase for the beams with ald of 6.0 was 32\%. Kwak et al. (2002) [18] carried out an experiment on $12 \mathrm{RC}$ beams to investigate the effect of steel fibers on the shear strength of slender beams without stirrups. The parametric study involved three different steel fiber volumes $(0,0.5$ and $0.75 \%)$, span-depth ratios ( 2,3 and 4$)$, and two concrete compressive strengths (31 and $65 \mathrm{MPa}$ ). The results showed an increase in the shear cracking and ultimate shear capacity as the volume of steel fiber and the compressive strength were increased. In 2003, Cho and Kim
[8] investigated the effect of steel fibers on RC beams subjected to shear load. The experiment consisted of 30 simply supported beams under two-point loads divided into 6 series. The parameters included steel fibers content (0$2.0 \%$ ), compressive strength (30-81 MPa), tensile reinforcement ratio (1.3-2.9\%), and the existing of stirrups. Test results showed that the inclusion of steel fibers considerably developed the initial stiffness, cracking shear and ultimate shear strength for both normal and high strength beams. The failure mode shifted from shear to flexure among NSC beams when the dosage of steel fibers reached $2.0 \%$. However, the failure mode shifted from shear to flexure among HSC beams when $1.5 \%$ steel fibers volume was added. The ultimate shear strength experienced a significant increase among NSC beams once the steel fibers volume became $1.0 \%$. In contrast, the remarkable increase in the ultimate shear strength among HSC beams came into effect when only $0.5 \%$ of steel fibers was added. An experimental work was conducted by Dinah et al. (2010) [13] aiming at studying the addition of different types of steel fibers in RC beams without stirrups. A total of 28 simply supported beams with shear span-depth ratio of 3.5 were constructed. The compressive strength was kept constant at $41 \mathrm{MPa}$. The parametric study accounted for steel fiber length ( 30 and $60 \mathrm{~mm}$ ), fiber aspect ratio (55 and 80), fiber volume fraction ranging from 0.75 to $1.5 \%$, and longitudinal reinforcement ratio including 1.6, 2.0 and $2.7 \%$. Test results revealed that the use of steel fibers caused multiple diagonal cracks with a great increase in the shear capacity. The study also suggested that the steel fibers could be confidently used as a minimum shear reinforcement in RC beams without stirrups.

Araújo et al. (2014) [9] conducted an experiment on $6 \mathrm{RC}$ beams to study the effect of steel fiber 
on the shear strength of slender beams. The parametric study involved two different steel fiber volumes (1 and 2\%). The study indicated that the use of steel fibers had significant effect on the shear capacity. The shear strength increased by $87 \%$ and $99 \%$ when the volume of steel fibers of $1 \%$ and $2 \%$ were added, respectively. The significance of steel fibers also reflected on shear crack, resulting in less crack width. The addition of steel fibers by $2 \%$ led the failure mode to shift from shear to bending.

\section{Research significant}

The present work highlights the importance of use of recycled concrete aggregate as a potential alternative means to produce satisfying concrete. Shifting towards using more recycled substances would serve less waste consumption and more economical solutions. The current research aims to see to what extent the recycled concrete aggregate can replace the conventional concrete aggregate. The approach is centered on the performance of reinforced concrete slender beams under shear loads with various mix design of concrete aggregate.

\section{Variables and Specimen Dimensions}

The tests program involved six simply supported beams. All beams were made of $1300 \mathrm{~mm}$ in length and same rectangular cross-section $(100 \times$ $150 \mathrm{~mm})$. The shear span-to-depth ratio (a/d) was kept constant at 2.5. The beams were tested under two-point loads and reinforced with two of 16 $\mathrm{mm}$ bars placed in the tension zone. Full details of specimens are illustrated in Figure 2 and Table 1. The parametric study is summarized as follows:

1. Type of aggregate: concrete was made with two types of aggregates including natural coarse and recycled aggregates. The latter was employed with two approaches; treated and untreated.

2. Addition of steel fibers $\left(\mathrm{V}_{\mathrm{f}} \%\right)$ : the test contained five beams incorporating $2 \%$ of steel fibers, while one beam remained clear from steel fibers.

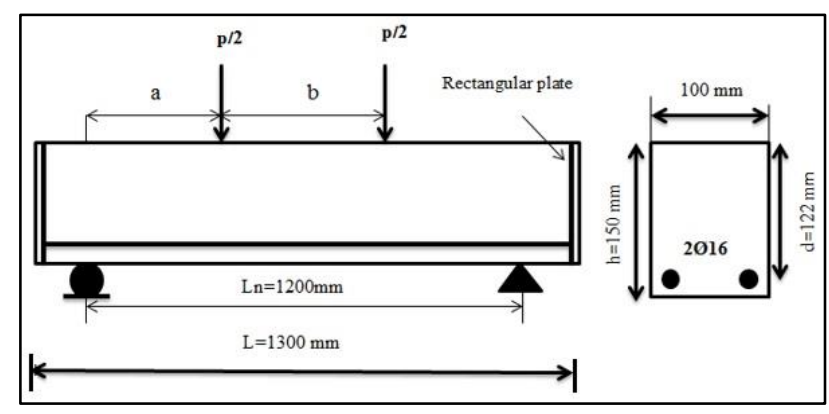

Figure 2. Beam specimen details

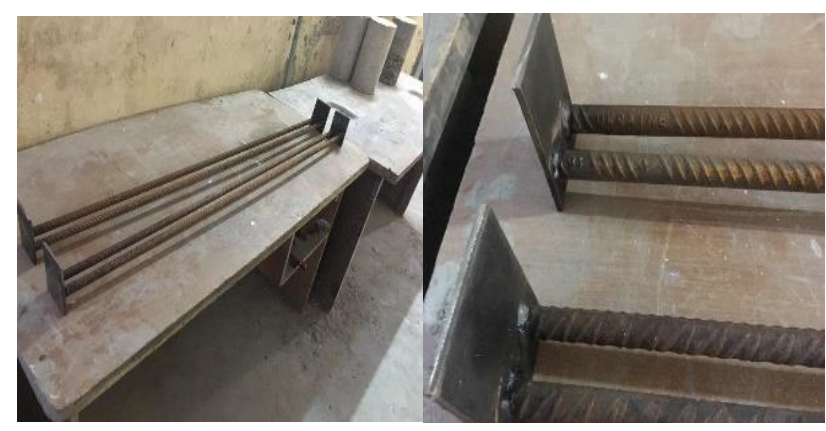

Figure 3. Details of reinforcement

Table 1. Details of test program and parameters

\begin{tabular}{|c|c|c|c|c|c|c|}
\hline Beam & $\mathrm{Vf}$ & SP* & S.F & ald & Steel & Aggregate \\
\hline No. & $(\%)$ & $\begin{array}{c}* \\
(\%)\end{array}$ & $(\%)$ & & $\begin{array}{c}\text { reinforc } \\
\text { ement }\end{array}$ & type \\
\hline $1 *$ & 2 & 6 & 20 & 2.5 & $2 \varnothing 16$ & $100 \%$ NCA \\
\hline 2 & 2 & 6 & 20 & 2.5 & $2 \varnothing 16$ & $50 \% \mathrm{NCA}$ \\
\hline & & & & & & $\begin{array}{l}50 \% \mathrm{RCA} \\
\text { (untreated) }\end{array}$ \\
\hline
\end{tabular}




\begin{tabular}{|c|c|c|c|c|c|c|}
\hline 3 & 2 & 6 & 20 & 2.5 & $2 \varnothing 16$ & $\begin{array}{c}100 \% \\
\text { untreated }\end{array}$ \\
\hline 4 & 2 & 6 & 20 & 2.5 & $2 \varnothing 16$ & $\begin{array}{l}50 \% \text { NCA } \\
50 \% \text { treated }\end{array}$ \\
\hline 5 & 2 & 6 & 20 & 2.5 & $2 \varnothing 16$ & $100 \%$ treated \\
\hline 6 & 0 & 6 & 20 & 2.5 & $2 \varnothing 16$ & $100 \%$ treated \\
\hline
\end{tabular}

\section{Experimental work}

\subsection{Materials}

Ordinary Portland cement (Type-1) produced by the United Cement Company (UCC), Bazian, Iraq, was used for the mix concrete design. The cement was checked according to the Iraqi standard IQ.S. No5/1984[15]. Clean sand extracted from Al-Khaddar region, Karbala along with broken gravel from Al-Nabaei area were considered in this research. The fineness modulus (FM) of sand was 2.6, whilst the specific gravity of gravel was 2.62. The gradient test for the utilized sand and gravel was according to Iraqi standards IQ. S (No45:1984) [14]. The concrete mixture was advanced with the addition of silica fume and superplasticizer (Glenium-51) to achieve better performance and durability. For those mixes with steel fibers, hooked-ends mild carbon steel fibers with an aspect ratio $\left(L_{f} \backslash D_{f}\right)$ of 80 were used for this purpose. All materials were mixed step by step with the help of tap water.

With respect to the concrete mixtures involving recycled aggregates, old cubes and cylinders were used as recycled coarse aggregates after being crushed to small pieces. The source of those old specimens involved the structural lab at 
mol as suggested by Ramli and Ismail (2013) [16]. This process has been previously found to be capable of removing and cleaning any impurities and slurry attached to the RCA's surfaces (Ismail and Ramli, 2013[16]and Tam et al., 2007) [23]. The soaking step had lasted 24 hours before the RCA was rinsed and washed then left to dry. After the dehydration, the aggregates were filtered from any unfavored small pieces using sieve No.4 in order to maintain a desirable size of aggregates.
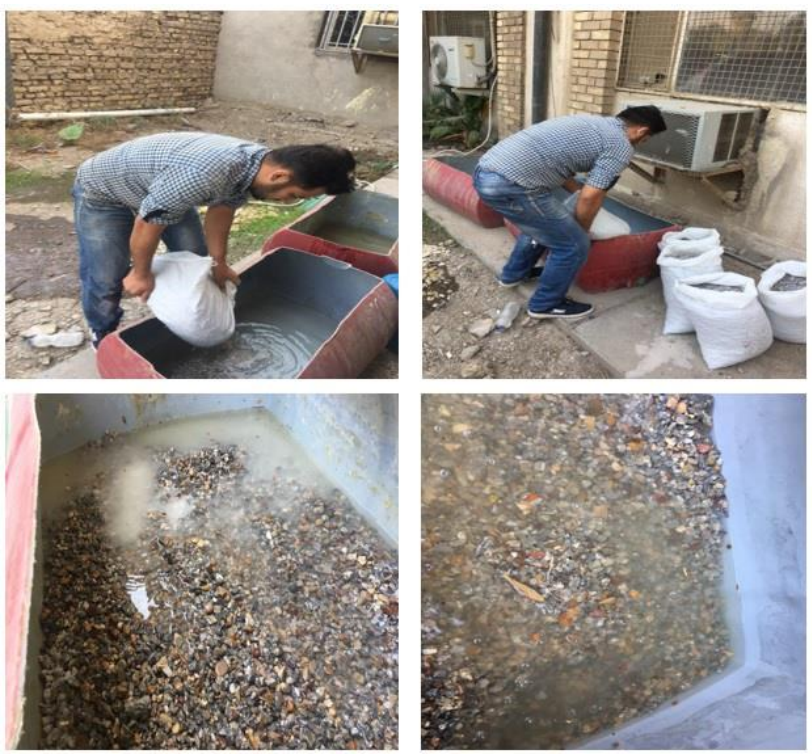

Figure 5. Soaking the RCA in a hydrochloric acid $(\mathrm{HCl})$

The second stage of treatment was accomplished by immersing the aggregates in a distilled water using a plastic container with $0.5 \mathrm{~mol}$ concentration of sodium-meta-silicate pentahydrate (see Figure 6). Using such acid was proved to coat the RCA's surfaces and fill the cracks and pores, which in turn, would lead for better bond strength between the aggregates and the new cement mortar. After one hour of coating, the aggregates were rinsed and left to dry so as to be used later to produce a recycled concrete. This essential process was successfully conducted by various studies (e.g. Cheng and Wang, 2005[12[ and Spaeth and Tegguer, 2013) [22].
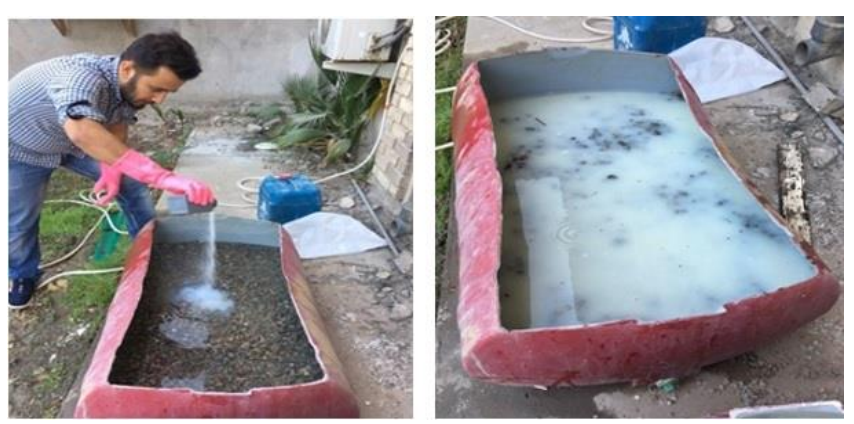

Figure 6. Coating the RCA in sodium metasilicate pentahydrate

\subsection{The concrete mixture}

Prior to utilizing the mixer, any of the remaining concretes from previous batch has been cleaned off. Damp cloth has been utilized for wiping the pan and mixer's blades. The Mixing ratio used in this work was (1:1.5:2). The water-cement ratio (wlc) handled in this research was 30\%. Figures (6) and (7) present the preparations and casting regarding the control specimen (prisms, cylinders, and cubes) and beams.
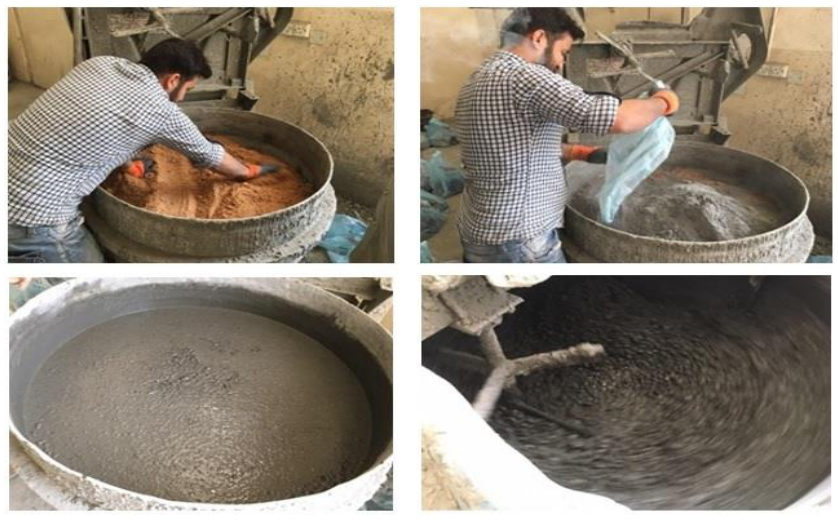

Figure 7. The Process of Mixing 

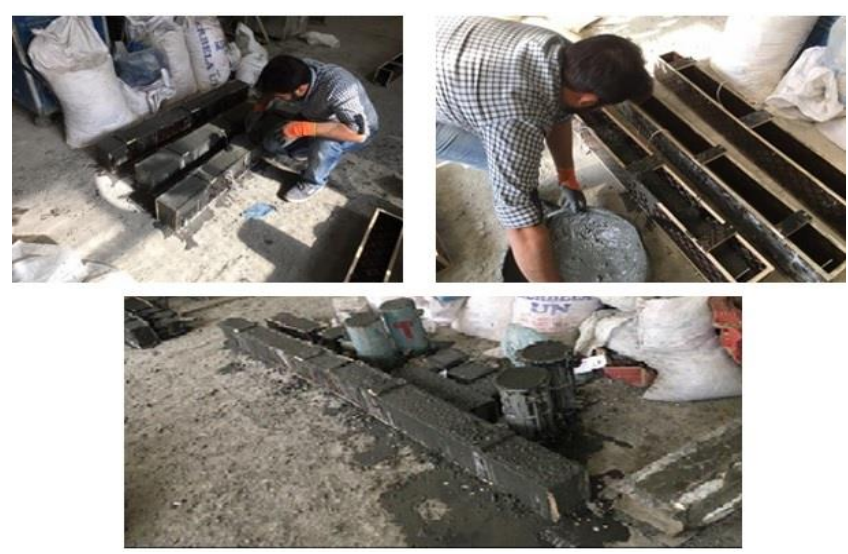

Figure 8. Casting and Preparation of specimens

\section{Test procedure}

All beams and control specimens were tested at age of 30-32 days. Prior to the day of the test, the $\mathrm{RC}$ beams had been cleaned and dyed with white color in order for the cracks to be easily monitored during the test. All beams were situated under two-point loads and the support were placed $50 \mathrm{~mm}$ away from each beam's end. During the test, the loading rate was kept at 5 $\mathrm{kN} / \mathrm{min}$. Meanwhile, the middle deflection was being recorded in parallel with the load reading using a sensitive dial gauge (0.01 $\mathrm{mm}$ precision). Steel plates with $4 \mathrm{~mm}$ thickness were welded to the end of the longitudinal bars. Those plates were provided to inhibit a potential bond failure during the test. Crack widths were being measured at different intervals with the help of stainless feeler gauge. For each beam, a set of 3 cubes $(100 \times 100 \times 100 \mathrm{~mm}), 2$ cylinders $(150 \times$ $300 \mathrm{~mm})$ and 1 prism $(100 \times 100 \times 500 \mathrm{~mm})$ were considered to determine the mechanical properties. Standard cubes and cylinders were used based on BS 1881: Part 116[6] in order to determine the compressive strength (fc) in 28 days. Splitting tensile strength $(f t)$ was performed on the basis of BS 1881: Part 117[7]. Modulus of rupture was achieved and loaded with $50 \mathrm{kN}$ hydraulic two-point loading machine based on (ASTM C78-02) [4].
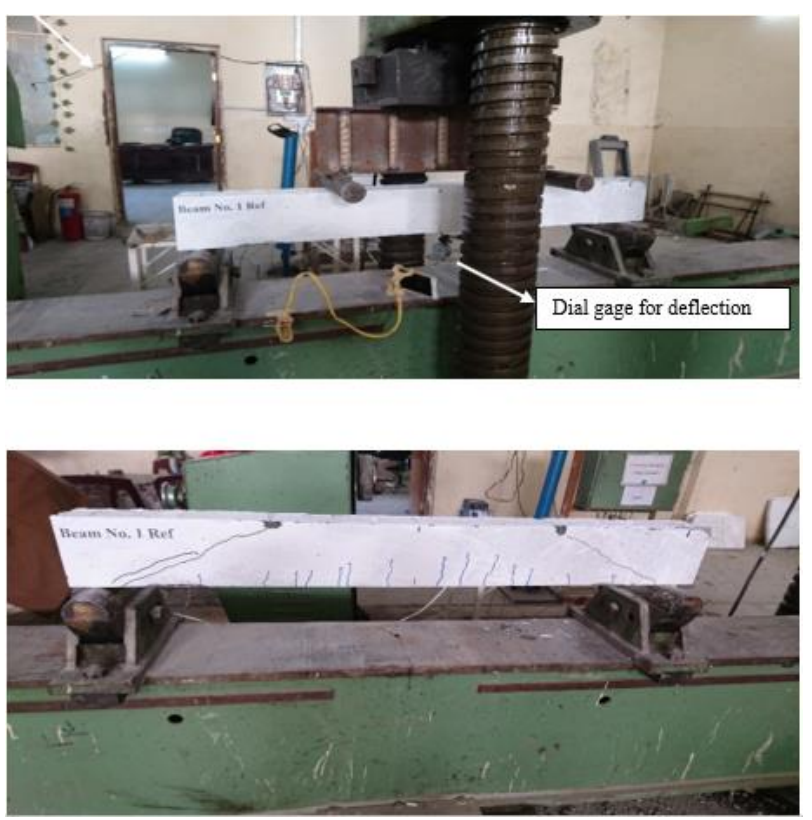

Figure 9. Setup of loading, position of dial gages

\section{Result and Discussion}

\subsection{Result of mechanical properties}

\subsubsection{Compressive strength:}

Test results obtained from the control specimens showed that the corresponding average of cubic and cylindrical compressive strengths for NCA were 64 and $61 \mathrm{MPa}$, respectively. Meanwhile, the corresponding compressive strengths among RCA specimens were remarkably lower than the reference values with NCA. Regarding specimens incorporating $50 \%$ and $100 \%$ treated RCA, cubic compressive strengths reduced almost $3.1 \%$ and $11.0 \%$, respectively when compared to their companions with NCA. Further reduction was observed when untreated RCA was used. For cubic mixes having $50 \%$ and $100 \%$ untreated RCA, $9.4 \%$ and $18.8 \%$ were reported to be the amount of reduction in compressive strength when compared to NCA. This reduction is attributed to the existence of the interfacial transition zone between the old adhered mortar and new coarse aggregate. Nevertheless, the gap in results were reasonably narrowed when RCA 
was chemically treated. Therefore, the findings promote the possibility of using the RCA, if properly treated, as a replacement to NCA. Such treatment was also reported in the past as an effective approach to enhance the mechanical properties of RCA (Katkhuda and Shatarat, 2016) [17].

\subsubsection{Splitting tensile strength $\left(f_{t}\right)$}

Table 2 contains the results from the control specimens including the splitting tensile stresses. Comparing to plain concrete (i.e. without steel fibers), it was clear that the splitting tensile stress developed about $r \wedge \%$ when $2 \%$ of steel fibers was added. The presence of steel fibers played significant role in controlling and delaying the cracks, which in turn reflected positively on the tensile stress behavior. The use of untreated recycle coarse aggregate with $50 \%$ and $100 \%$ reduced the splitting tensile stress by $15 \%$ and $9.5 \%$, respectively compared to cast samples from natural coarse aggregate. It was interesting to observe that the use of treated RCA offered close compromise to the values obtained from NCA. This is another evidence of how RCA could provide close agreement in results with NCA.

\subsubsection{Flexural strength $\left(f_{r}\right)$}

The findings indicated a considerable enhancement in the flexural strengths among specimens with steel fibers when compared to their companion without steel fibers. This development could be attributed to the steel fibers which enrich the ductility of concrete. A negligible scatter was found in the flexural strengths between the specimens having 50\% and $100 \%$ recycled treated aggregate and NCA. The change was merely $1 \%$ and $4.6 \%$, respectively. However, using untreated RCA tended to widen the gap regarding the flexural strengths to the favor of NCA

Further reduction was noticed when untreated RCA was used for mixes having 50\% and $100 \%$ untreated with $7 \%$ and $15 \%$ reported to be the amount of reduction in flexural strength when compared to NCA.

Table 2. Mechanical properties of hardened concrete

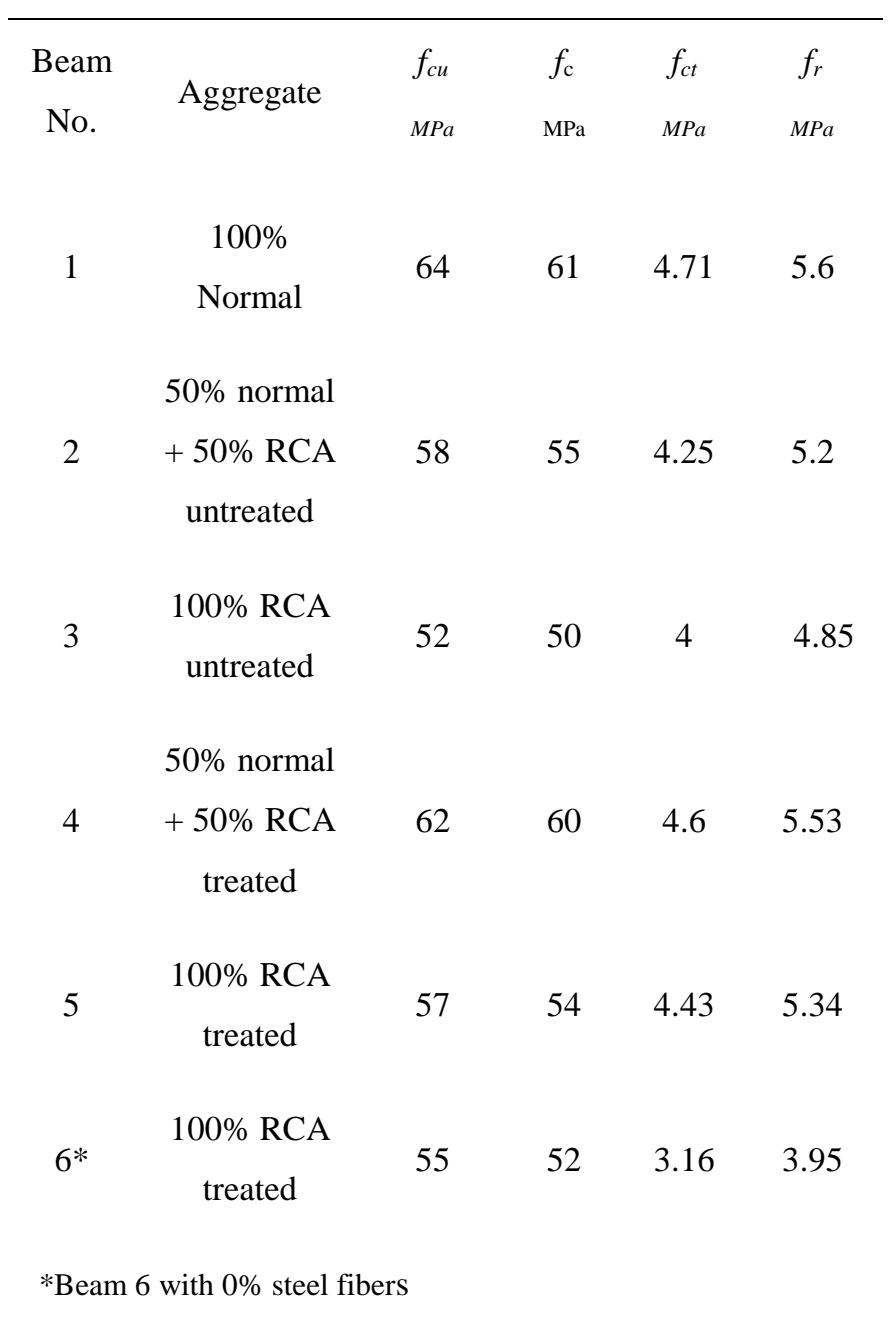

\subsection{Result of tested beams}

Table (3) shows the following results:

\section{Crack patterns and failure mechanism}

All tested beams ended with diagonal tension shear failure mode. The existence of steel fibers had a significant influence on the rate of crack growth and crack widths. All beams had almost similar linear crack growth starting in the areas adjacent to the supports. At early loading stage, an inclined tensile crack had commenced across the shear span between the applied load and support. By the time goes, the crack had deepened inside 
nearby the tensile reinforcement. As the test reached the ultimate load, the diagonal crack had extended across the shear span in the direction of applied load and approached the compression zone. The shear failure mode in all beams is illustrated in Figs. 12-17. Results related to the structural behavior of RC beams are summarized in Table (3).

\section{Impact of coarse aggregate:}

When other parameters remained constant, the values of the ultimate load taken from (NCA) are higher than the ones obtained from (RCA). Because RCA comes with angular shapes. The identified that the irregularity of RCA contribute to lower workability of concrete (Batayaneh, M., Marie, I., Asi, I, (2007) [5]. Past researchers had proved that the absorption rates of Recycled aggregate are higher compared with normal coarse aggregate (Diah and majid,1998)[10] (Poon, C.S., Shui, Z.H., Lam, L., Kou, S.C.,2004)[20] (Tam, V. W., \& Tam, C. M. 2007)[24].The RCA has a high porosity so that the bonding with the rest of the concrete components is fragile. Furthermore, the interfacial transition zone (ITZ) between the old and new mortar had established weak zones which then resulted in less ultimate shear loads. The percentage of reduction in ultimate load for mixes having $50 \%$ untreated and $100 \%$ untreated was $10.5 \%$ and $27.6 \%$, respectively when compared to NCA. The negative influence of untreated coarse aggregates was subsided with proper chemical treatment. The acid removed the adhered mortar on a recycled aggregate and the sodium metasilicate pentahydrate filled the pores and crack. The discrepancy in the ultimate load for mixing having $50 \%$ and $100 \%$ treated RCA was only $1.9 \%$ and $9 \%$, respectively as compared to the values taken from NCA.

\section{The effect of steel fibers:}

The addition of steel fibers into the concrete significantly improved the toughness of high strength concrete. As expected, the beams containing steel fibers exhibited more ultimate loads compared with the other beams tested without using steel fibers. This enhancement is mainly due to the presence of steel fibers, which developed beam stiffness and consequently increases the ultimate load. The steel fibers also delayed the appearance of cracks in the beams and reduced their widths. The increase in the ultimate load of beams containing steel fibers by $2 \%$ is about $36 \%$ compared to the beams with a content of $0 \%$ for the same type of aggregate.

Table. (3) Test result of beams

$\begin{array}{cccccc}\text { Beam } & \text { Vf } \% & \text { S.F } \% & \text { Pcr } & \text { Pu } & \begin{array}{c}\Delta \\ \text { No. }\end{array} \\ & & & \mathrm{kN} & \mathrm{kN} & \\ & & & & & \\ 1 & 2 \% & 20 \% & 34 & 105 & 7.84 \\ 2 & 2 \% & 20 \% & 27 & 94 & 6.2 \\ 3 & 2 \% & 20 \% & 20 & 76 & 5.77 \\ 4 & 2 \% & 20 \% & 32 & 103 & 7.5 \\ 5 & 2 \% & 20 \% & 30.5 & 95.5 & 6.93 \\ 6 & 0 \% & 20 \% & 14 & 61 & 4\end{array}$

\section{Load-deflection Relationships}

The corresponding ultimate shear load and deflection for B1 which contains normal aggregates were $105 \mathrm{kN}$ and $7.84 \mathrm{~mm}$, respectively. The use of RCA caused the ultimate load and deflection to be generally lower than their companion obtained from NCA. When using un treated RCA, a reduction in ultimate load and deflection was observed. The percentage of reduction for deflection mixes having $50 \%$ for B2 and $100 \%$ for B3 untreated RCA were respectively $21 \%$ and $26.4 \%$ lower 
than the values taken from NCA. In contrast, the use of $50 \%$ treated RCA (B4) with steel fibers made the ultimate shear load and deflection to be reasonably close to their companion obtained from NCA. Although the recorded ultimate shear load and deflection from 100\% treated RCA (B5) experienced slight reduction as compared to B1, the scatter did not exceed $10 \%$ and such difference can be considered quite satisfying. This suggests that RCA, if chemically treated, can provide similar structural behavior to NCA and be promising substitute material in future. Figs. 10-11 show load-deflection relationships for tested beams.

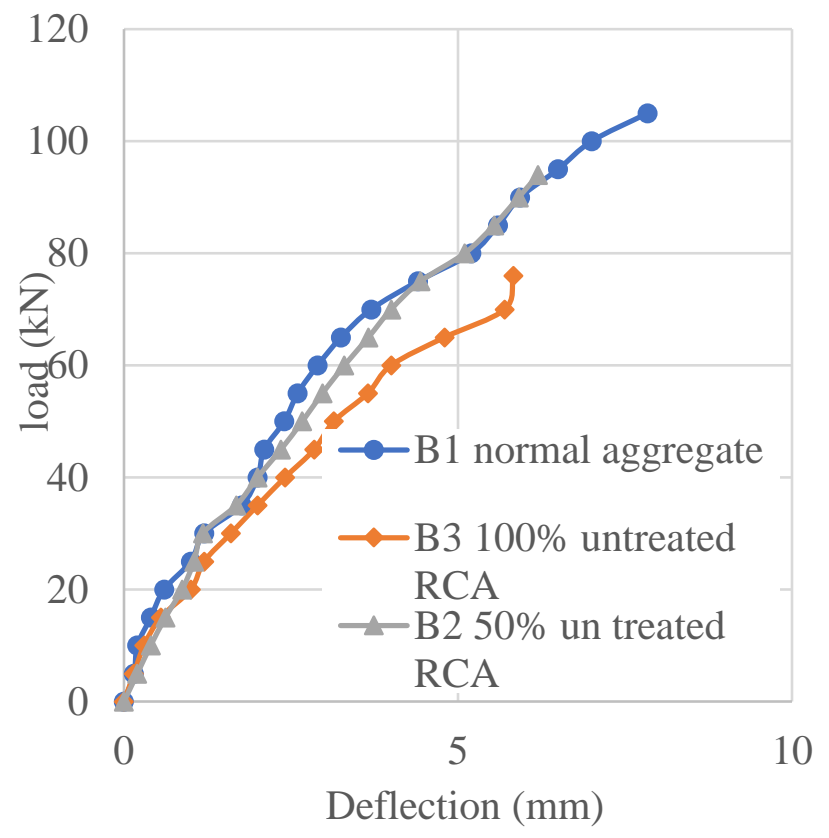

Figure 10. Effect of untreated RCA on load-deflection Relationship

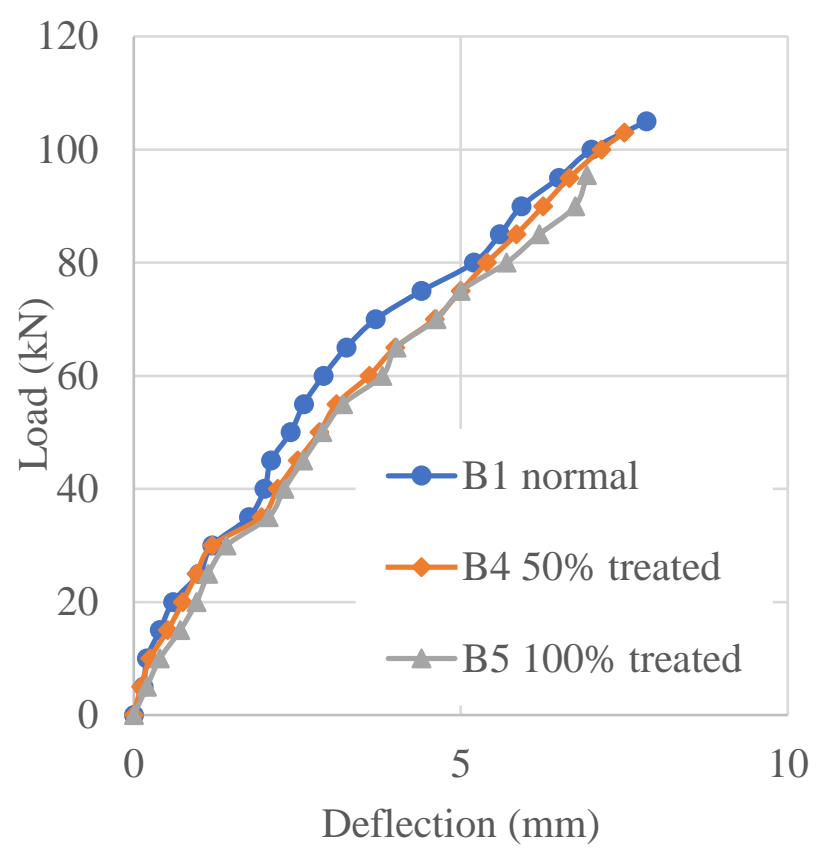

Figure 11. Effect of treated RCA on load-deflection Relationships

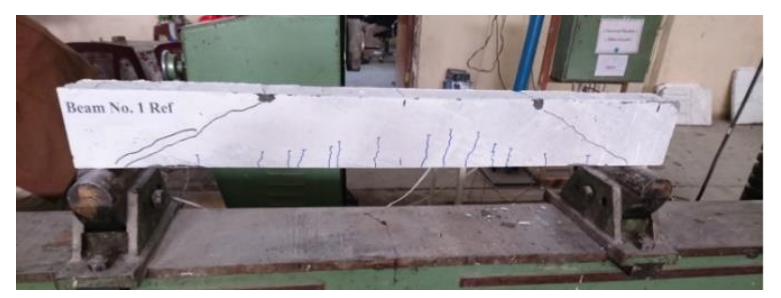

Figure 12. Mode of failure of beam specimen (1)

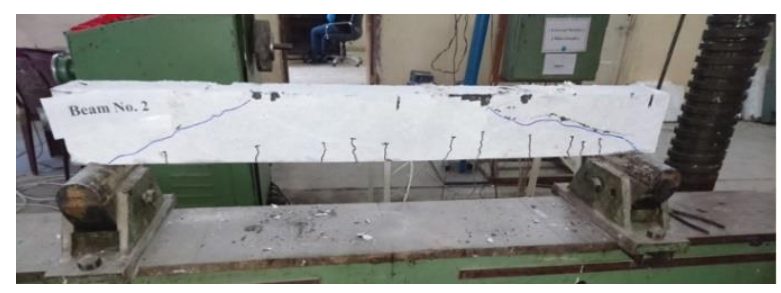

Figure 13. Mode of failure of beam specimen (2)

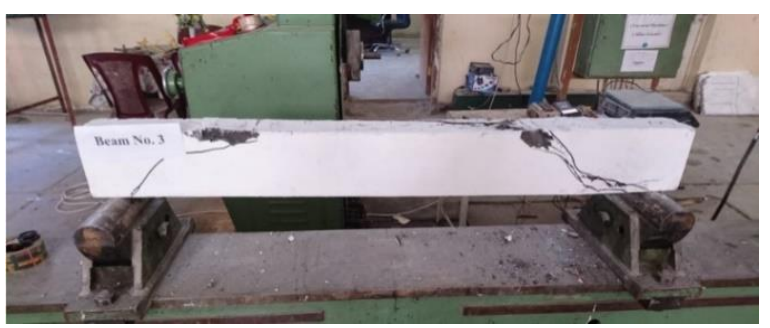

Figure 14. Mode of failure of beam specimen (3) 


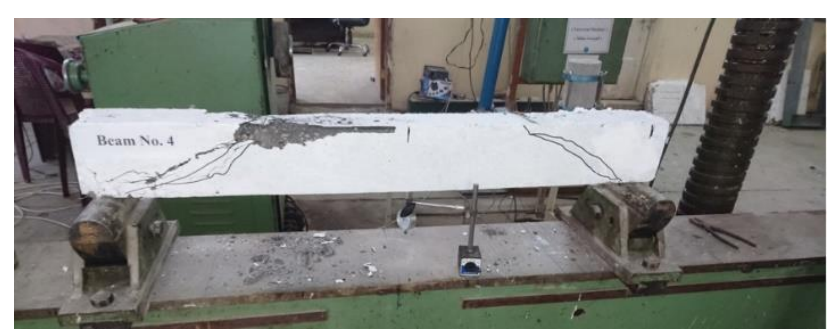

Figure 15. Mode of failure of beam specimen (4)

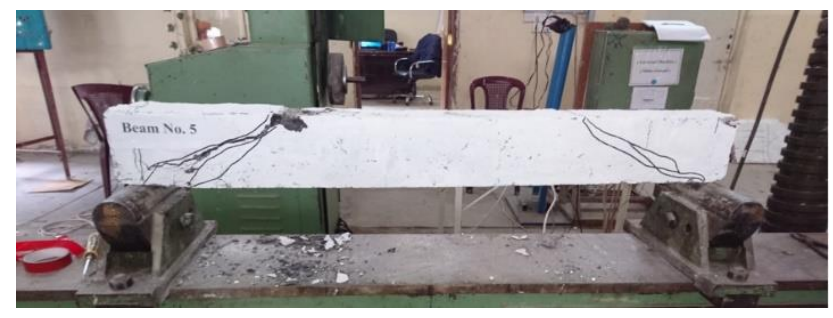

Figure 16. Mode of failure of beam specimen (5)

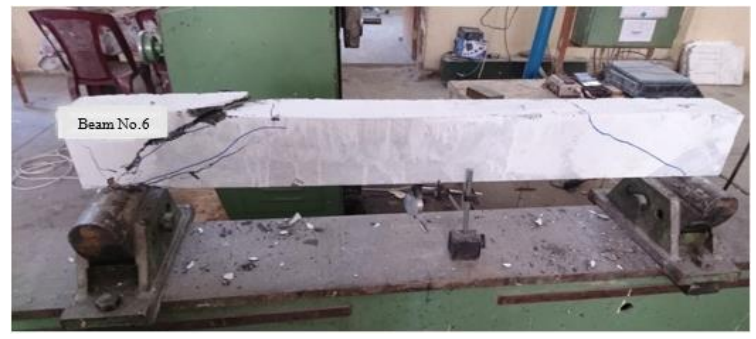

Figure 17. Mode of failure of beam specimen (6)

\section{Conclusion}

Some significant points regarding this research can be presented below:

1. The values of the ultimate load of (NCA) are greater than the values of mixes used (RCA), when other parameters were kept constant. Because, the RCA has a high porosity in addition to the leftover mortar remains to the surface of the aggregates that the bonding with the rest of the concrete components is fragile. The percentage of reduction in ultimate load for mixes having $50 \%$ untreated and $100 \%$ untreated was $10.5 \%$ and $27.6 \%$, respectively when compared to NCA.

2. The negative effect of untreated coarse aggregate was subsided when the mixes were treated by hydrochloric acid (HCL). The sodium metasilicate pentahydrate is filling the crack and pores, while the acid is removing adhered mortar on the recycled aggregate. The discrepancy in ultimate load for mixing having 50\% and $100 \%$ treated RCA was only $1.9 \%$ and $9 \%$, respectively as compared to the values taken from NCA.

3. The use of RCA caused the compressive strengths to be generally lower than their companion obtained from the NCA.The percentage of reduction for cubic mixes having $50 \%$ treated and $100 \%$ treated was respectively $3.1 \%$ and $11.0 \%$ lower than the values taken from NCA.Further reduction was noticed when untreated RCA was used. For cubic mixes having $50 \%$ untreated and $100 \%$ untreated, $9.4 \%$ and $18.8 \%$ were reported to be the amount of reduction in compressive strength when compared to NCA.

4. Test results provided considerable enhancement in shear capacity along with considerable delay in the cracking load when steel fibers were added. The increment in ultimate load regarding the beams that contain steel fibers by $2 \%$ is about $36 \%$ compared to the beams with a content of $0 \%$ for the same type of aggregate. The splitting tensile stress of samples containing $0 \%$ steel fiber is $28 \%$ less than samples with steel fibers of $2 \%$.

\section{Conflict of interest}

The authors of this articles certify that mention of the publication of this article cause no conflict of interest.

\section{Abbreviations}

$\mathrm{a} / \mathrm{d}$

Shear span/depth ratio

B

Width of beam mm

C \& D Construction and Demolition 
distance from extreme

D compression fiber to Centroid of tension $\mathrm{mm}$

$\mathrm{F}$

$f_{\mathrm{c}}^{\prime}$

Compressive strength of concrete $\mathrm{MPa}$

$f_{c f}^{\prime} \quad$ Compressive strength of fibrous concrete

$f_{r}$

$f_{\mathrm{t}}$

F.M

$\mathrm{H}$

HSC

ITZ

$\mathrm{L}_{f} / \mathrm{D}_{f}$

$\mathrm{L}$

Ln

NCA

$\mathrm{RC}$

RCA

RHSC Recycled high strength concrete

$\mathrm{P}$

$\mathrm{Pu} \quad$ Ultimate load of tested beam $\mathrm{kN}$

Pcr First crack load kN

Vf Volumetric ratio of steel fiber

$\mathrm{Vu} \quad$ Maximum shear capacity $\mathrm{MPa}$
S. F

SP

wlc

$\Delta \mathrm{o}$

pw
Silica fume

Superplasticizer

Water to cement ratio

Deflection at ultimate load $\mathrm{mm}$

Longitudinal reinforcement

\section{References}

1. ACI Committee 318 (2019) Building Code Requirements for Structural Concrete: An ACI Standard: Commentary on Building Code Requirements for Structural Concrete. American Concrete Institute.

2. ACI Committee 446. ," Fracture Mechanics of Concrete: Concepts, Models and Determination of Material Properties ", ACI 446, I R-91, American Concrete Institute, Detroit, 1989. Cited by ASCE-ACI Committee 445, (1998).

3. Ashour, S. A., Hasanain, G. S., \& Wafa, F. F. (1992). Shear behavior of high-strength fiber reinforced concrete beams. Structural Journal, 89(2), 176-184.

4. ASTM C78-02. 2014. Standard Test Method for Flexural Strength of Concrete (Using Simple Beam with Third-Point Loading. Annual Book of American Society for Testing Concrete and Materials, Philadelphia, Pennsylvania.

5. Batayaneh, M., Marie, I., \& Asi, I. (2007). Use of selected waste materials in concrete mixes. Waste management, 27(12), 18701876.

https://doi.org/10.1016/j.wasman.2006.07.02 6

6. BS 1881-116 "Method for determination of compressive strength of concrete cubes" British Standards Institute, London, 1983. 
7. BS 1881-117 "Method for determination of splitting tensile stress " British Standard Institute, London, 1983.

8. Cho, S. H., \& Kim, Y. I. (2003). Effects of steel fibers on short beams loaded in shear. Structural journal, 100(6), 765-774.

9. De Lima Araújo, D., Nunes, F. G. T., Toledo Filho, R. D., \& de Andrade, M. A. S. (2014). Shear strength of steel fiber-reinforced concrete beams. Acta Scientiarum. Technology, 36(3), 389-397.

10. Diah and Majid. (1998). "Penggunaan sisa kiub sebagai Aggregate', at jurutera, pp 4450 .

11. Etxeberria, M., Vázquez, E., Mari, A. and Barra, M. (2007) "Influence of amount of recycled coarse aggregates and production process on properties of recycled aggregate concrete", Cement and Concrete Research, 37(5), pp. 735-742. DOI https://doi.org/10.1016/j.cemconres.2007.02.002.

12. H.L. Cheng, C.Y. Wang (2005) "The influence of sodium silicate on the properties of recycled aggregate" Gypsum Cem. Build. 12, pp. 12-14.

13. Hai H. Dinh, Gustavo j. Parra- Montesinos, and james k. wight. (2010). Shear behavior of steel fiber-reinforced concrete beams without stirrups reinforcement. ACI structural journal /October 2010.

14. Iraqi Specification, No. 45/1984, "Aggregate from Natural Sources for Concrete and Construction", Central Agency for Standardization and Quality Control, Baghdad, 1984.

15. Iraqi Specification, No. 5/1984, "Portland Cement", Central Agency for Standardization and Quality Control, Baghdad, 1984.

16. Ismail, S., \& Ramli, M. (2013). Engineering properties of treated recycled concrete aggregate (RCA) for structural applications. Construction and Building
Materials, 44, 464-476.

DOI: https://doi.org/10.1016/j.conbuildmat.2013.03.01 4.

17. Katkhuda, H. and Shatarat, N. (2016) "Shear behavior of reinforced concrete beams using treated recycled concrete aggregate", Construction and Building Materials, 125, pp. 63-71. DOI: https://doi.org/10.1016/j.conbuildmat.2016.08.03 4

18. Kwak, Y. K., Eberhard, M. O., Kim, W. S., \& Kim, J. (2002). Shear strength of steel fiberreinforced concrete beams without stirrups. ACI Structural Journal, 99(4), 530538.

19. Matias, D., de Brito, J., Rosa, A., \& Pedro, D. (2014). Durability of concrete with recycled coarse aggregates: influence of superplasticizers. Journal of materials in civil engineering, 26(7),

06014011.

DOI:https://doi.org/10.1061/(ASCE)MT.19435533.0000961

20. Poon, C. S., Shui, Z. H., Lam, L., Fok, H., \& Kou, S. C. (2004). Influence of moisture states of natural and recycled aggregates on the slump and compressive strength of concrete. Cement and concrete research, 34(1), 31-36.

21. Rao, A., Jha, K.N. and Misra, S. (2007) "Use of aggregates from recycled construction and demolition waste in concrete", Resources, conservation and Recycling, 50(1), pp. 71-81. DOI:https://doi.org/10.1016/j.resconrec.2006.05. 010

22. Spaeth, V., \& Tegguer, A. D. (2013). Improvement of recycled concrete aggregate properties by polymer treatments. International 1 Journal of Sustainable Built Environment, 2(2), 143152.

DOI https://doi.org/10.1016/j.ijsbe.2014.03.003

23. Tam, V. W., Tam, C. M., \& Le, K. N. (2007). Removal of cement mortar remains from 
recycled aggregate using pre-soaking approaches. Resources, Conservation and Recycling, 50(1), 82-101. DOI:https://doi.org/10.1016/j.resconrec.2006 .05 .012 .

24. Tam, V. W., \& Tam, C. M. (2007). 'Crushed aggregate production from centralized combined and individual waste sources in Hong Kong'. Construction and Building Materials, 21(4), 879-886.DOI: https://doi.org/10.1016/j.conbuildmat.2005.1 2.016

25. Salah A Aly, Mohammed A Ibrahim, and Mostafa M Khattab. (2015) "Shear Behavior of Reinforced Concrete Beams Casted with Recycled Coarse Aggregate "European Journal of Advances in Engineering and Technology, 2(9), pp. 59-71.

26. Seyedhamed Sadati, Mahdi Arezoumandi, Kamal H. Khayat, Jeffery S. Volz. (2016) "Shear performance of reinforced concrete beams incorporating recycled concrete aggregate and high-volume fly ash", Journal of Cleaner Production ,115, pp. 284-293. https://doi.org/10.1016/j.jclepro.2015.12.017.

27. Xiao, J., Li, W., Fan, Y. and Huang, X. (2012) "An overview of study on recycled aggregate concrete in China (1996-2011)" Construction and Building Materials, 31, pp. 364-383.DOI: https://doi.org/10.1016/j.conbuildmat.2011.1 2.074

28. Sami W. Tabash. And Sheriff Yehia. (2018) "Shear Strength of Reinforced Concrete Beams Made with Recycled Aggregate", Proceedings of the 3rd World Congress on Civil, Structural, and Environmental Engineering (CSEE'18). 